\title{
HVOF Sprayed Mullite Coatings for Use In Extreme Environments
}

\author{
Viswanath Bellie $^{1} \cdot$ Joghee Suresh $^{2} \cdot$ Lingaraj Ragunath $^{2}$ \\ ${ }^{1}$ Department of Mechanical Engineering, New Horizon College of Engineering, Marathalli Road,Bangalore-560103, Karnataka, \\ India. \\ ${ }^{2}$ Department of Chemistry, Sri Ramakrishna Engineering College, Coimbatore - 641022 (T.N.) India.
}

\section{ABSTRACT}

Products used in industry and marine applications are exposed to extreme environments like high heat, humidity, acidic or alkaline or hyper saline environment, UV and IR radiation. Metals with good corrosion and oxidation resistance may be used but are restricted to $\mathrm{Ni}$ and $\mathrm{Cr}$ alloys, titanium and super alloys etc., which are costly and have their limitations. Hence ceramic coatings on low cost metals may be an answer to this problem. Ceramics are inherently chemically inert, high temperature resistant, corrosion and oxidation resistant. Flame spraying of ceramics is a good and reliable method for applying ceramic coatings on metallic substrates with good bond strength ( $>80 \mathrm{MPa}$ ) and $1 \%$ porosity. In this work, HVOF technique is applied to obtain 100 microns thick mullite coatings on MS substrates with a NiCr bond coat. Mullite has a high oxidation and corrosion resistance. It is chemically inert. It has high temperature resistance even at $2000^{\circ} \mathrm{C}$. These properties are ideal for industrial components exposed to salty environments. Characterization studies like XRD, SEM/EDS, Corrosion tests using polarization technique, coating thickness and surface roughness have been studied and reported. A corrosion rate of $1.55 \mathrm{~mm} /$ year has been achieved in a sea water environment.

COIndian Thermal Spray Society and INScienceIN. 2020. All rights reserved
ARTICLE HISTORY

Received 05-02-2020

Revised 29-02-2020

Accepted 04-03-2020

Published 18-03-2020

\section{KEYWORDS}

Extreme Environments Mullite

Oxidation Resistance Corrosion Resistance

Tafel Plots

\section{Introduction}

Materials with good chemical inertness, oxidation and corrosion resistance and mechanical strength are in demand for many extreme environments like in chemical plants, marine applications, structures, manufacturing plants, aerospace and automobile applications to name a few. Products used in industry and service are exposed to extreme environments like high heat, humidity, acidic or alkaline or hyper saline environment, UV and IR radiation. Traditionally used materials like Nickel and chromium alloys, titanium alloys and super alloys are costly and not economically viable for large installations. A cost effective solution is the use of ceramic overlay coatings on low cost metallic substrates. Advanced Ceramic materials have all the required properties to enhance the life of the substrate used for extreme environments. Thermal spraying is one such technique used for coating ceramics like Zirconia, alumina, silica, mullite,Yittria stabilized Zirconia, Titania etc. Among the ceramic materials, fused mullite produced by fusion technique is one candidate material with good properties like high temperature resistance, low thermal conductivity, oxidation and corrosion resistance and chemical inertness.

Mullite is a suitable material for use in structural ceramic applications due to its high temperature strength and creep resistance. It has a high melting point of $1830^{\circ} \mathrm{C}$, good electrical resistance, good mechanical strength, low thermal expansion coefficient ( $\left.4.5 \times 10^{-1}\right)$, low electrical conductivity and low dielectric constant $(\varepsilon=56.5$ at $1 \mathrm{MHz})$ and good chemical and thermal shock resistance properties. It is used in refractory applications, electronic applications, protective coatings, electrical insulators, for gas turbine components and optical fields [1-2].
Mullite has been successfully plasma sprayed on aluminum substrates for IC engine applications [3].Many research studies have been conducted on usage of ceramic material coatings using thermal spray techniques for extreme environments.

In one study to protect metallic components from heat, oxidation and corrosion in hostile environments, $\mathrm{Ni}-20 \mathrm{Cr}$ bond coat and $\mathrm{CaZrO}_{3}$ top coat wereapplied on $316 \mathrm{SS}$ substrates by air plasma spray coating technique [4]. Unconventional nanoscale composite coatings of SHS7170 were made for boiler applications, where elevated temperature erosion plays a major role[5]. Zirconium oxide coatings were deposited on stainless steel, AISI 316L, 2205, and tool steel AISI D2, using the ultrasonic spray pyrolysis method. The corrosion resistance of the coatings was evaluated in an ammonia atmosphere. The zirconia coating was found to improve the resistance to corrosion [6]. Highly corrosion and wear resistant chromium carbide $\left(\mathrm{Cr}_{3} \mathrm{C}_{2}\right)$ based cermet coatings have been thermally sprayed onto traditional fluidized bed combustors (FBC) operating with ecological waste and biomass fuels [7]. A bi-layer Alloy-718/NiCrAlY coating was deposited on grey cast iron substrate using the HVOF technique. The coating showed enhanced high temperature oxidation and erosion resistance [8]. In one study, titanium, an oxygen-sensitive material was applied as corrosion-resistant barrier coating on carbon steel using cold gas dynamic spraying technique and the effects of porosity on the corrosion behavior was investigated [9]. Future gas turbine engines need advanced thermal barrier coatings (TBCs) with lower thermal conductivity, higher resistance to calcium-magnesiumaluminosilicate (CMAS), and improved high-temperature performance, compared to traditional yttria-stabilized zirconia (YSZ) TBCs, for higher efficiency. A double-layer 
rare-earth zirconate/YSZ TBCs has been tried using the solution precursor plasma spray (SPPS) process for high temperature humidity conditions [10]. Carbon nanotube (CNT)-reinforced aluminum oxide $\left(\mathrm{Al}_{2} \mathrm{O}_{3}\right)$ composite coatings was plasma-sprayed and the wear behavior was investigated at room temperature (298 K), elevated temperature $(873 \mathrm{~K})$, and in sea water [11]. Cold spraying method has the distinction of producing pure and dense metallic coatings and along with a protective oxide layer, plays a major role in corrosion resistance. Studies were conducted on two cold sprayed tantalum coatings to investigate the microstructural details, denseness, and corrosion resistance [12].Low cost carbon steel pipes are used for the transport of $\mathrm{CO}_{2}$ due to their low corrosion rates in an atmosphere of dry $\mathrm{CO}_{2}$. But in the presence of liquid water, $\mathrm{CO}_{2}$ forms corrosive carbonic acid. Hence to reduce corrosion of carbon steel in sea water thermally sprayed aluminum (TSA) has been used [13].New materials like refractory (e.g., W, Mo) silicide alloys and $\mathrm{SiC}$ composites are used to enhance the high temperature capability. Thermal spray coatings of Molybdenum followed by chemical vapor deposition of Silicon and Boron by pack cementation has been carried out to develop an aluminoboro silica surface for improved environmental resistance [14].In one study, detonation-gun-sprayed $\mathrm{Ni}$ $5 \mathrm{Al}$ coatings were applied on Ni based super alloy Inconel718 and a comparative study of the high temperature hot corrosion behavior of bare and coated specimens were carried out. The studies were carried out in $\mathrm{Na}_{2} \mathrm{SO}_{4}-60 \%$ $\mathrm{V}_{2} \mathrm{O}_{5}$ molten salt environments at $900^{\circ} \mathrm{C}$ for 100 cycles of heating and subsequent cooling [15]. One study evaluates the oxidation and hot corrosion resistance of high velocity oxy-fuel (HVOF) sprayed WC-NiCrFeSiB coating deposited on two super alloys, Ni-based (Superni75) and Fe-based (Superfer $800 \mathrm{H}$ ). The specimens of both coated and uncoated ones were exposed to air and molten salt $\left(\mathrm{Na}_{2} \mathrm{SO}_{4}-25 \% \mathrm{NaCl}\right)$ environment at $800^{\circ} \mathrm{C}$ under cyclic conditions [16].In one study, high velocity oxy fuel (HVOF) spraying was used to deposit stainless steel $316 \mathrm{~L}$ (UNSS31603) and nickel alloy 625 (UNS N06625) coatings onto a carbon steel substrate. The electrochemical corrosion behavior of the as-prepared coatings has been compared against their respective materials in wrought form [17]. In one study, corrosion and slurry erosioncorrosion (E-C) behavior of FeCrMoMnWBCSi amorphous metallic coatings (AMCs) and 304 stainless steel was investigated by static electrochemical measurements and weight loss tests under rotating conditions in simulated seawater. The AMCs are preferentially attacked at coating defects. The superior E-C resistance of AMCs can be attributed to the high micro hardness, alloying elements and amorphous microstructure [18].Iron based amorphous coatings are considered to be more effective to combat erosion corrosion problems in fluid handling equipment such as propellers, impellers, pumps in warships, submarine. High velocity oxy-fuel (HVOF) spray process is considered to be a better process to coat the iron based amorphous powders. In this investigation, iron based amorphous metallic coating was developed on 316 stainless steel substrate using HVOF spray technique [19]. Corrosion resistant coatings for the marine structural steels require impermeability and cleanliness. An inert gas shroud system was attached with the commercial HVOF apparatus. The coating of Hastelloy $\mathrm{C}$ nickel base alloy was formed on steel, demonstrated an excellent protective performance over 10 months in the marine exposure test
[20]. Maritime hydraulic components are often exposed to harsh environmental conditions which can lead to accelerated deterioration, reduced function, equipment failure and costly repair. Two leading causes of maritime hydraulic failure are biofouling accumulation and corrosion. One of the current standard coatings used for hydraulic actuator piston rods in marine vessels is an air plasma spray (APS) coating of ceramic, such as aluminatitania(Al203-TiO2). Three coating types were novel high velocity oxygen fuel (HVOF) carbide-based coatings, while the fourth coating was the air plasma spray (APS) ceramic coating. This study examined the antifouling performance of the coatings. Following 20 weeks immersion at tropical and temperate field exposure sites, the control APS ceramic accumulated significantly greater levels of biofouling compared to the HVOF coatings [21].

In this work, HVOF technique is adopted to apply 100 microns thick mullite coatings on MS substrates with a $\mathrm{NiCr}$ bond coat. Mullite is chemically inert and stable at elevated temperature of up to $2000^{\circ} \mathrm{C}$, has a high oxidation and corrosion resistance and no change takes place when exposed to salty environments. The aim is to develop a coating for corrosion resistance in a marine environment.

\section{Experimental}

\section{Materials \& Methods}

Mild steel (with approximately $0.05-0.25 \%$ carbon) plates of size $50 \mathrm{~mm} \times 50 \mathrm{~mm} \times 10 \mathrm{~mm}$ thickness was machined to size and one face of size $50 \times 50 \mathrm{~mm}$ was sand blasted to a surface roughness of 3.17 microns average Ra value. The sand blasted specimens were thermally sprayed with a bond coat of Nickel Chrome and a second coat of mullite using HVOF technique. The composition and properties of mullite and Nickel Chrome are given in Tables 1 and 2 below. Nickel Chrome powder supplied by Powder Alloy Corporation, USA; specifications:- PAC98F1 REV C NICKEL CHROMIUM, PWA1319F: Particle size: 45 to 75 microns.

Table 1: Chemistry of fused Mullite

\begin{tabular}{ccccc}
\hline Constituent & $\mathrm{Al}_{2} \mathrm{O}_{3}$ & $\mathrm{SiO}_{2}$ & $\mathrm{Fe}_{2} \mathrm{O}_{3}$ & $\mathrm{Na}_{2} \mathrm{O}$ \\
\hline Value* & $78 \%$ & $21.6 \%$ & $0.05 \%$ & $0.35 \%$ \\
& $*$ As analyzed on size $-16+30$ & ASTM sieves & \\
\hline
\end{tabular}

Table 2: Particle chemistry of nickel chrome powder

\begin{tabular}{|c|c|c|c|c|c|c|c|}
\hline \multicolumn{2}{|c|}{ Element } & $\mathrm{C}$ & $\mathrm{Cr}$ & $\mathrm{Fe}$ & $\mathrm{Mn}$ & $\mathrm{Ni}$ & $\mathrm{Si}$ \\
\hline \multicolumn{2}{|c|}{$\begin{array}{c}\text { Composition } \\
\text { (Wt. \%) }\end{array}$} & 0.015 & 19.58 & 0.35 & 0.004 & 78.6 & 1.29 \\
\hline \multirow[t]{2}{*}{ Spec } & Min & & 18.00 & & & & \\
\hline & Max & 0.25 & 21.00 & 1.00 & 2.50 & 80.0 & 1.50 \\
\hline
\end{tabular}

High purity Bayer alumina, pure quartz sand, rock crystals and fused silica wax were used as starting materials to prepare fused mullite of stoichiometric composition $3 \mathrm{Al}_{2} \mathrm{O}_{3} .2 \mathrm{SiO}_{2}$. The materials were supplied by $\mathrm{M} / \mathrm{s}$ Carborundum Universal, Kalamaserry, India. The raw materials were fused and melted in a tilting type electric furnace above $2000^{\circ} \mathrm{C}$ and subsequently cast into molds followed by air cooling to room temperature, during which crystallization of mullite took place. The grits formed were of macro size. The castings are subsequently crushed, cleaned of magnetic impurities using high intensity magnetic separators and graded into desired sizes. The Nickel Chrome bond coat material was commercially available. Nickel chrome in the ratio $80 \% / 20 \%$ and particle size 40 to $75 \mu \mathrm{m}$ was kept ready after drying in an oven for 2 hours for spraying the bond coat. Mullite powder 


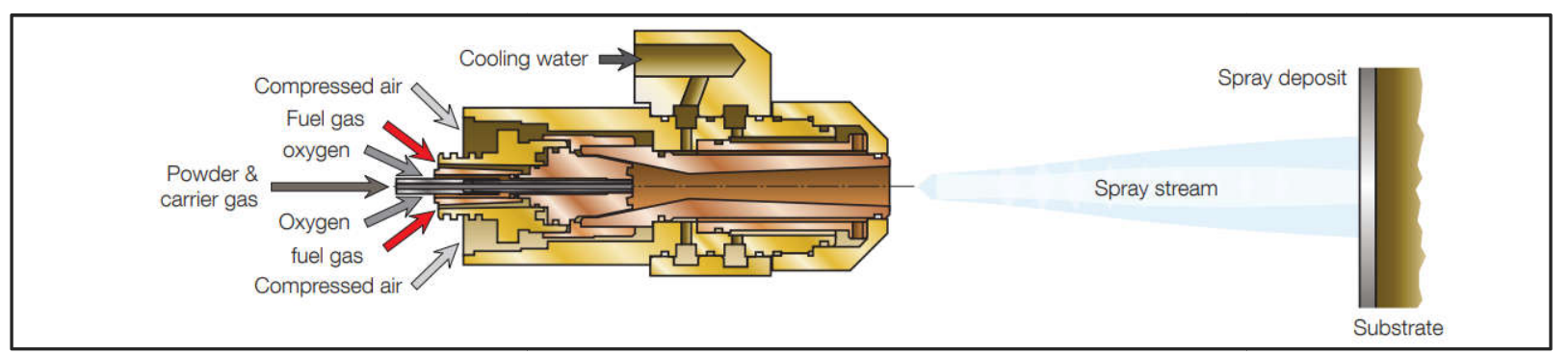

Figure 1: Gas-Fuel HVOF process

comprising of $70 \% \mathrm{Al} 2 \mathrm{O} 3$ and $30 \% \mathrm{SiO} 2$, in the size range 40 to $60 \mu \mathrm{m}$ was ball milled, blended, and stored in heating ovens for 2 hours prior to HVOF spraying, and applied as the top coat. METCO ROBOT HVOF spraying equipment consisting of a control system, a spray gun, a powder feeder, a cooling water pump and connecting hoses was used to fabricate the different specimens in this study.

The HVOF process used $\mathrm{H}_{2}$ as fuel at a combustion pressure of $0.55 \mathrm{MPa}$, gas velocity of $2000 \mathrm{~m} / \mathrm{s}$, particle velocity of $500 \mathrm{~m} / \mathrm{s}$, axial feed powder injection (hotter zone), a higher powder injection pressure and spray rate up to $120 \mathrm{~g} / \mathrm{min}$. The gun used is a water cooled Metco HVOF, 2700 Diamond jet model. The gas -Fuel HVOF Gun is shown above in the Fig. 1.The HVOF spraying was carried out at M/s Aum Surface Technology, Bangalore.

Characterization studies like XRD, SEM/EDS, Coating thickness, coating roughness and polarization studies were carried out to understand the morphology and physical/chemical nature of the coated surface and to recommend its suitability for many extreme environment applications. X-Ray Diffraction study was conducted using the equipment model D8 ADAVANCE ECO, X-Ray Source - 1 KW Cu K $\alpha(\lambda=1.54 \mathrm{~A})$, Geometry - Bragg-Brentano $(\theta-\theta)$,

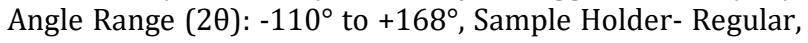
Sample Stage- Rotating, Detector- SSD 160 detector. Scanning Electron Microscope/Electro dispersive spectroscopy studies were conducted with Hitachi Make and Model S 3500, with Detectors - BSE and SE, Resolution - $30 \mathrm{~nm}$, with a maximum Magnification of up to $300,000 \mathrm{k}$, Coating- Carbon and gold, Accessories - Cooling stage for observing viscous or gel like materials.SEM images were used to study the microstructure of the coated surface and EDS studies provided the elemental analysis. Coating thickness play's a major role in determining the strength of adhesion of the coating onto the substrate. Studies have proved that a lower coating thickness up to even 3 microns prevents delamination of the coating and provides a higher service life. A higher coating thickness leads to poor strength of the coating due to residual stresses and more defects. Hence it is imperative to measure the coating thickness. Magnetic induction instrument was used for the study. Coating thickness meter Model CM 8829 was used for the study. A rough surface of the substrate is required to enhance the adhesion of the deposit. The coated deposit gets into the troughs and valleys in the surface and gets interlocked with the base metal. Hence it is imperative to measure the surface roughness after sand blasting. A standard contact type profilometer is generally used in such studies. Roughness parameters like $\mathrm{Ra}, \mathrm{Rq}$ and $\mathrm{Rz}$ are measured. The profile roughness parameters standards used are BS EN ISO 4287:2000 British standard/ISO 4287:1997 standard. Mitutoyo Model number SJ 210 was used for the study. The corrosion characteristics depend on the metal/solution system under consideration. The test consists of a polarization cell consisting of an electrolyte solution, a reference electrode, a counter electrode(s), and the metal sample (working electrode) of interest connected to a specimen holder. The electrodes are connected to an electronic instrument called a potentiostat. The working, reference, and counting electrodes are placed in the electrolyte solution, which resembles the actual application environment of the material being tested. In the solution, an electrochemical potential (voltage) is generated between the various electrodes. The potentiostat measures the corrosion potential ( $E_{\text {corr }}$ ) which is the energy difference between the working electrode and the reference electrode.

For potentiodynamic experiments, the applied potential is increased with time and the current is constantly monitored. The current (or current density) is plotted verses the potential. After the potential is scanned to a predetermined current density or potential, the potential scan may be reversed while the current continues to be measured. This method is referred to as reverse polarization or cyclic polarization [22].The experimental set up for the test is shown in Figure 2 and 3 (photo) below.

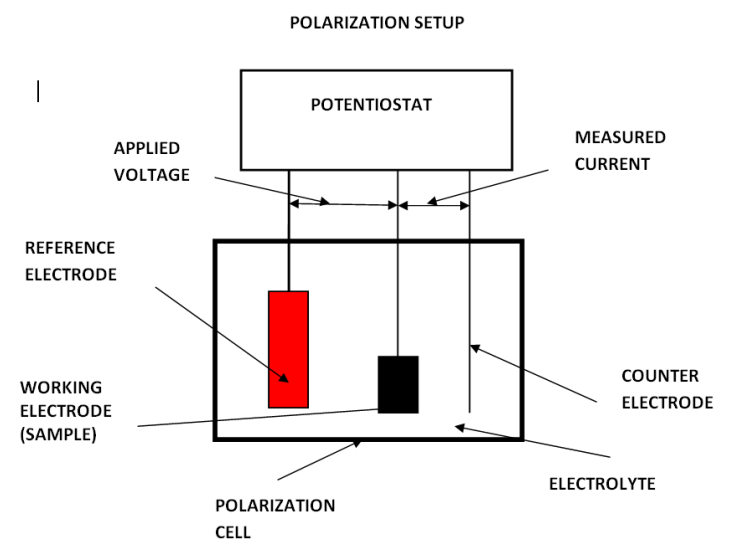

Figure 2: Polarization Setup

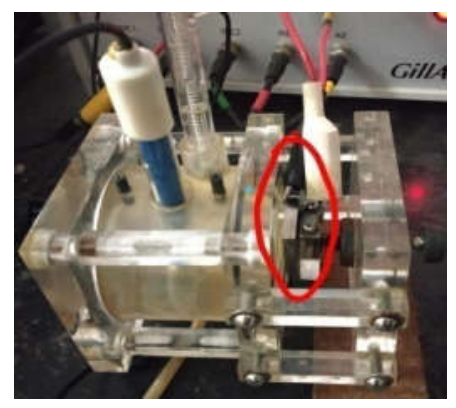

Figure 3: Image of setup 


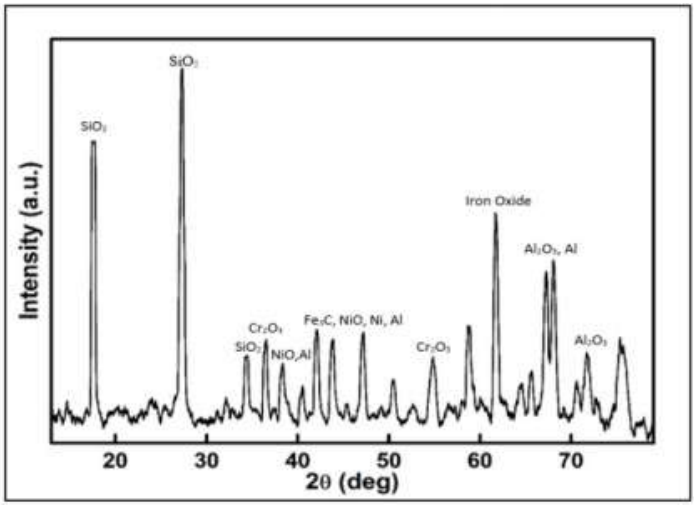

(a)

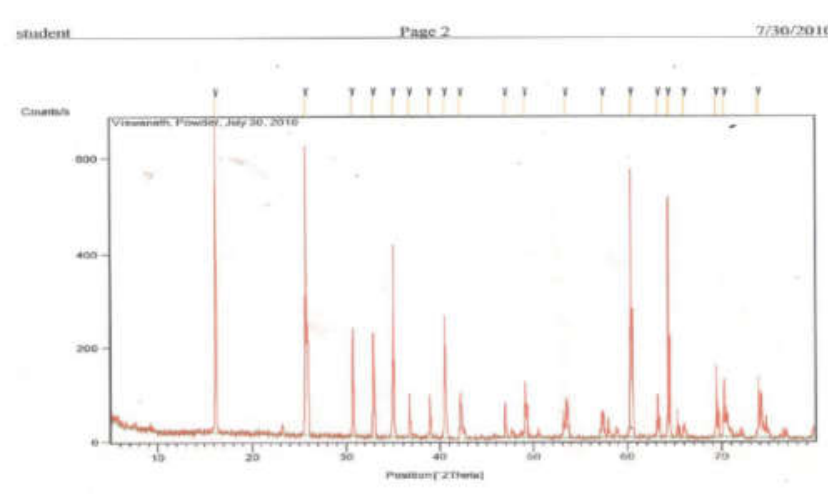

(b)

Figure 4: (a) XRD plot of the coated specimen, (b) powder

The coated test specimen was mounted in the setup and the electrolyte solution was filled in the cell. The coated surface was kept facing a hole provided in the setup to get the exposure and the uncoated surface was facing towards the viewer. An exposure of 24 hours duration was given for arriving at the corrosion rate.

A graphical plot (logarithmic) showing the relationship between the current generated in an electrochemical cell and the electrode potential of a specific metal is called as tafel plot. The results are based on electrochemical experiments performed under controlled conditions. Software by name OriginLab was used to extract the data and for plotting.

Polarization studies were conducted with sea water collected from the Bay of Bengal and synthetic water prepared in the laboratory. Synthetic water consists of sodium chloride (kitchen salt)-30g, potassium chloride$0.8 \mathrm{~g}$, Magnesium sulfate- $6.6 \mathrm{~g}$, sodium hydrogen carbonate$0.5 \mathrm{~g}$, Calcium chloride-1.3g. Both the water samples were acidic with $\mathrm{PH}$ of 8-8.5. As the sea water had the same composition as the synthetic water, results are presented for sea water only.

\section{Results and Discussion XRD studies}

The XRD plot shows the aluminum oxide and silicon dioxide ceramic phases in the coated structure. The clear peaks show the structure is crystalline in nature. The intensity of the aluminum oxide and silicon dioxide phases is high due to the higher weight percentage of the above materials. Low intensity nickel and chromium oxides are also seen as the bond coat contains the same. It is clear from the above that thermal spraying produces an oxide layer above the bond coat and below the top coat which will act as an additional barrier for extreme environments. The XRD plot of the coated specimen is shown above in Fig. 4.

\section{Scanning Electron Microscope studies}

The SEM images at $100 \mathrm{X}, 500 \mathrm{X}, 1000 \mathrm{X}, 2100 \mathrm{X}, 5000 \mathrm{X}$ and $10,000 \mathrm{X}$ are shown below in Figure 5. SEM images depict the splat morphology of the coating at different magnifications. The structure is representative of thermal spraying method like Plasma spraying and HVOF. The overlap of sprayed particle is visible in the images as solidification takes place gradually. Voids, porosity, cracks and unmelted particles are also seen in the images. Because of the presence of these defects, the coating is less dense and it is prone to corrosion. These results reflect in the corrosion rate with a higher rate due to less dense coating. A better process control, use of vacuum or a shroud inert gas is recommended to obtain a denser coating.

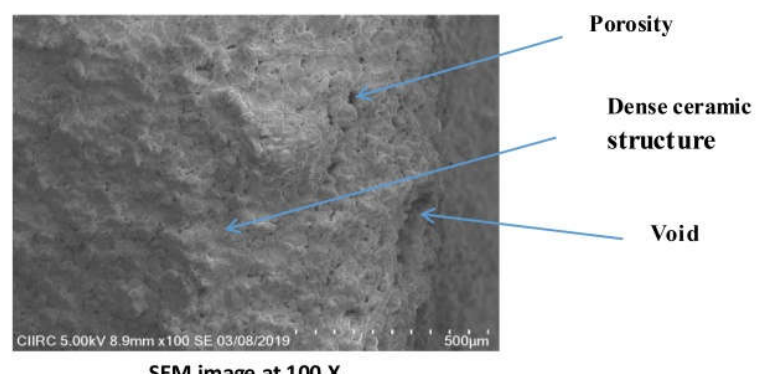

SEM image at $100 \mathrm{X}$

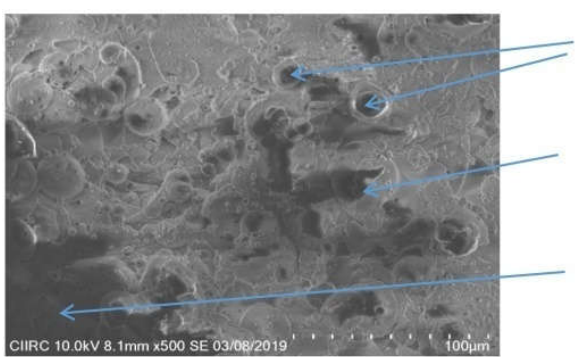

Porosity

Cracks

Void

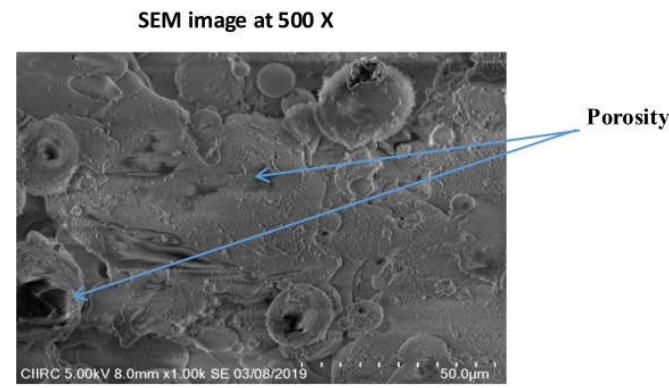

SEM image at $1000 \mathrm{X}$

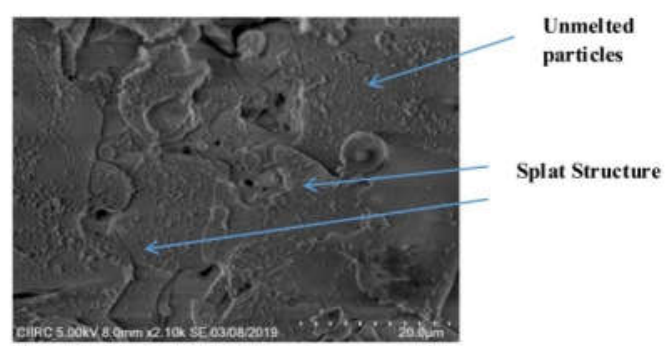

SEM image at 2100x 


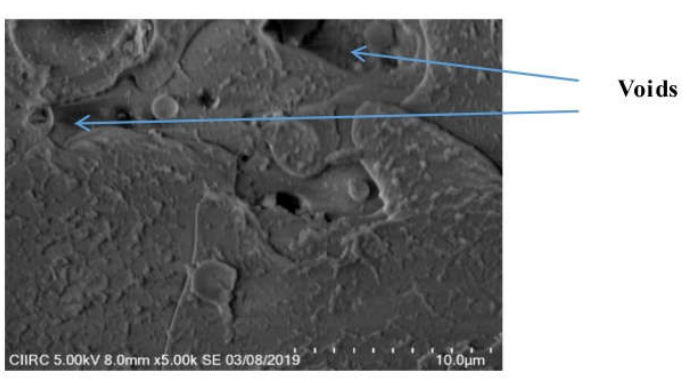

SEM image at $5000 x$

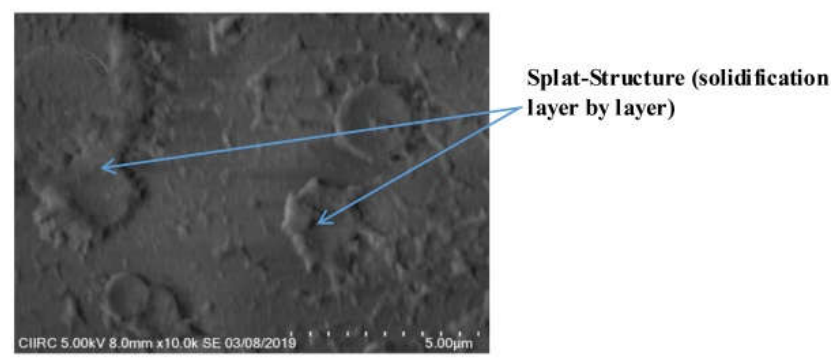

SEM image at $10000 x$

Figure 5: SEM images shows the splat morphology of the coating and a network of pores, cracks and voids, unmelted particles

\section{Energy Dispersive Spectroscopy (EDS) Studies}

Figure 6 below shows the EDS spectrum for the coated specimen and Table 3 shows the quantitative results.

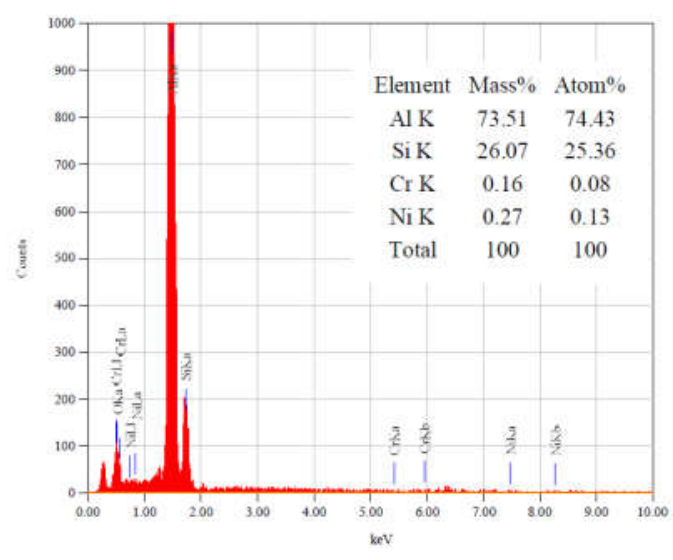

Figure 6: EDS plot of the coated specimen

Table 3: EDS Quantitative results

\begin{tabular}{ccccc}
\hline $\begin{array}{c}\text { Element } \\
\text { Line }\end{array}$ & Weight \% & $\begin{array}{c}\text { Weight \% } \\
\text { Error }\end{array}$ & Atom \% & $\begin{array}{c}\text { Atom \% } \\
\text { Error }\end{array}$ \\
\hline O K & 34.34 & \pm 0.82 & 47.50 & \pm 1.13 \\
Al K & 49.95 & \pm 1.14 & 40.97 & \pm 0.93 \\
Si K & 13.36 & \pm 0.81 & 10.53 & \pm 0.64 \\
Si L & ------ & --- & -- \\
Cr K & 2.35 & \pm 2.35 & 1.00 & \pm 1.00 \\
Cr L & --- & --- & --- & --- \\
Fe K & --- & --- & --- & -- \\
Fe L & 0.00 & --- & 0.00 & \pm 0.00 \\
Ni K & ------ & -- \\
Ni L & 0.00 & --- & 0.00 & \pm 0.00 \\
Total & 100.00 & & 100.00 & \\
\hline
\end{tabular}

The EDS plots reveal the presence of the elementsAluminium, Silicon, Oxygen, and traces of Nickel, and Chromium with a higher weight percentage of aluminium, silicon and oxygen due to these elements present in the ceramic top coat. The presence of the bond coat material may be due to a higher network of porosity and voids of the top coat at some local zones.

\section{Coating Thickness Results}

Table 4 below shows readings taken at 10 different location's on the coated surface for the measurement of coating thickness.

Average thickness of the coating consisting of the bond coat and the top coat on mild-steel is $283.5 \mu \mathrm{m}$. A lower thickness is desired to improve the adhesion of the coating on the substrate. Thermal spraying using HVOF technique provides thickness in the above range, which is acceptable for many applications.

Table 4: Coating Thickness measurements

\begin{tabular}{cccc}
\hline $\begin{array}{c}\text { Trial } \\
\text { No. }\end{array}$ & $\begin{array}{c}\text { Coating } \\
\text { Thickness } \\
(\mu \mathrm{m})\end{array}$ & $\begin{array}{c}\text { Trial } \\
\text { No. }\end{array}$ & $\begin{array}{c}\text { Coating } \\
\text { Thickness } \\
(\mu \mathrm{m})\end{array}$ \\
\hline 1 & 252 & 6 & 296 \\
2 & 260 & 7 & 271 \\
3 & 270 & 8 & 294 \\
4 & 269 & 9 & 316 \\
5 & 258 & 10 & 349 \\
\hline & Average & 283.5 \\
\hline
\end{tabular}

\section{Surface Roughness Results}

The surface roughness measurements are shown for the bare sand blasted MS specimens and the ceramic coated specimens in the Table 5 below.

Surface roughness of mild steel samples is shown in the table, which is required for the coating adhesion to take place. The roughness is more in the ceramic coated layer due to the layered formation of splats during spraying. A buffing operation if required can be carried out to improve the surface finish.

Table 5: Surface Roughness: Ra-Average Ratio, Rq-Root Mean Square, Rz-Average distance between highest peak and lowest valley

\begin{tabular}{cccc}
\hline Materials & $\operatorname{Ra}(\mu \mathrm{M})$ & $\operatorname{Rq}(\mu \mathrm{m})$ & $\operatorname{Rz}(\mu \mathrm{m})$ \\
\hline $\begin{array}{c}\text { Sand Blasted } \\
\text { MS }\end{array}$ & 3.153 & 3.845 & 14.771 \\
\hline $\begin{array}{c}\text { Ceramic } \\
\text { Coated MS }\end{array}$ & 5.475 & 6.671 & 26.946 \\
\hline
\end{tabular}

\section{Corrosion Rate Results}

Tafel plots and the results are shown below for the sea water base. The Icorr value of $0.1338116 \mathrm{~mA} / \mathrm{cm}^{2}$ for sea water base and corrosion rate of $1.55 \mathrm{~mm} /$ year were measured for the coated samples. Tafel plots and corrosion rate of stainless steel and MS have been studied for comparison. Tafel plots of the AISI 316 stainless steel and AISI 1010 carbon steel showed an Icorr measurement of -4 $\mathrm{mA} / \mathrm{cm} 2$ and $-2 \mathrm{~mA} / \mathrm{cm} 2$ respectively as per literature [23]. The electrolyte consisted of $3.0 \mathrm{wt} \%$ solution of chloride ions and the test was conducted at a temperature of $24^{\circ} \mathrm{C} \pm 1.0^{\circ} \mathrm{C}$; scan rate of $0.5 \mathrm{mV} \cdot \mathrm{s}-1$.This implies a low corrosion rate for SS 316 and Carbon steel 1010. Refer to Figure 7 for the tafel plots.

I corr values (ranging from 8 to $50 \mathrm{~mA} / \mathrm{cm}^{2}$ )and corrosion rates (ranging from 0.904 to $5.921 \mathrm{~mm} /$ year are much higher in the case of bare MS specimens tested in sea water as per literature [24].Figure 8 shows the tafel plot for sea water base and table 6 shows the measured values of the 
process parameters. Figure 9 shows the test specimen before and after polarization test.
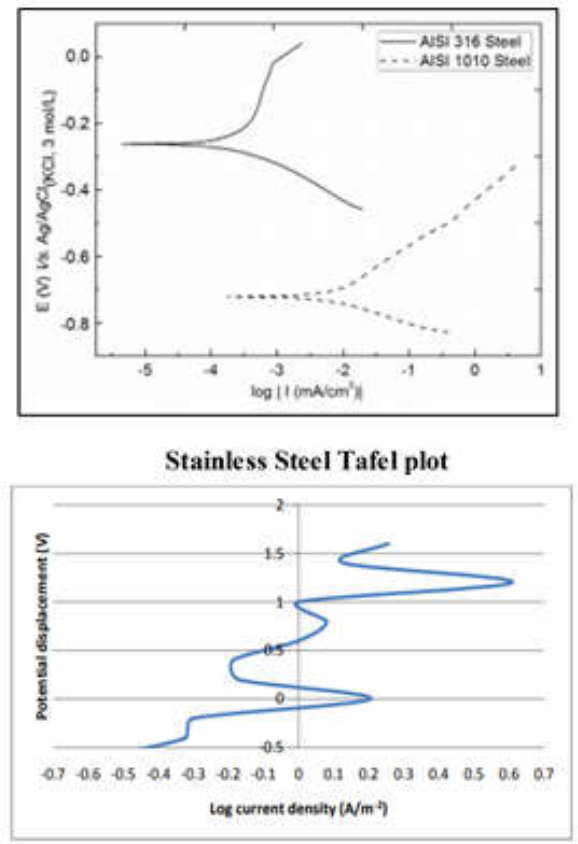

Tafel plot for Mild Steel( Sea Water Base)

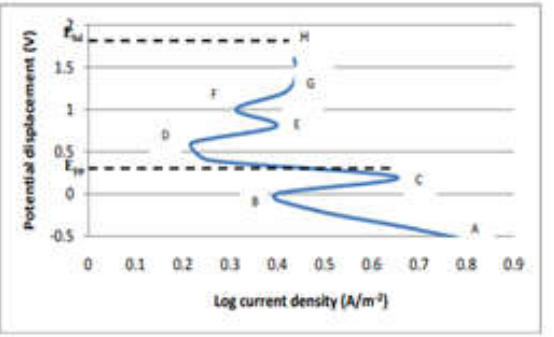

Tafel plot for Mild Steel (Synthe tic Water Base)

Figure 7: Tafel plot for SS and MS

Table 6: Corrosion rate results of coated specimens in sea water

\begin{tabular}{cc} 
base & \\
\hline Test type & Cyclic sweep \\
\hline Area $\left(\mathrm{cm}^{2}\right)$ & 1 \\
Rest Potential $(\mathrm{mV})$ & -563.62 \\
Metal & Mild Steel \\
Metal factor & 1163 \\
LPR (Ohm.cm $\left.{ }^{2}\right)$ & 207.8 \\
Ba (mV) & 80.254 \\
Bc (mV) & 314.92 \\
Icorr (mA/cm $\left.{ }^{2}\right)$ & 0.1338116 \\
Corrosion Rate (mm/year) & 1.5562 \\
Corrosion rate (mils/yr) & 61.268 \\
Intercept (mA/cm $\left.{ }^{2}\right)$ & 0 \\
Intercept corrosion rate (mm/year) & 0 \\
Intercept corrosion rate (mils/yr) & 0 \\
IR Compensation value $\left(\mathrm{Ohm} . \mathrm{cm}^{2}\right)$ & $\mathrm{N} / \mathrm{A}$ \\
Start Potential & $-300 \mathrm{mV}$ \\
Reverse Potential & $700 \mathrm{mV}$ \\
Sweep Rate & $2.778 \mathrm{mV} / \mathrm{min}$ \\
Cycles & 1.5 \\
Readings Per Test & Automatic \\
Cell Settle Time & $5 \mathrm{~seconds}$ \\
Limit at & $400 \mathrm{~mA} / \mathrm{cm}^{2}$ \\
\hline
\end{tabular}

JTSE Vol. 2 (1), 2020, pp 43-49

Contents lists available at http://www.inscience.in/JTSE.html

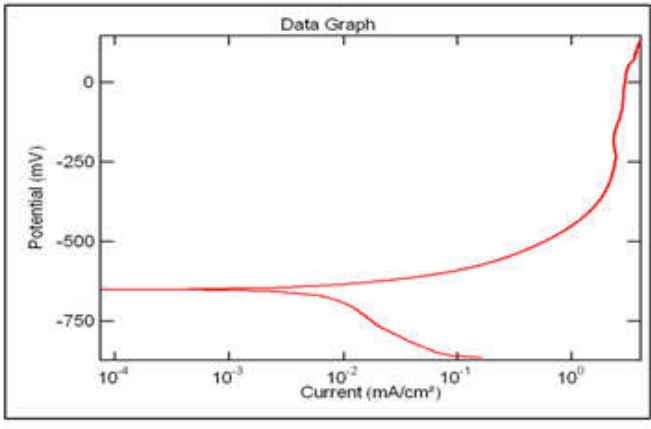

Tafel Plot for sea water

Figure 8: Tafel Plot for coated specimens

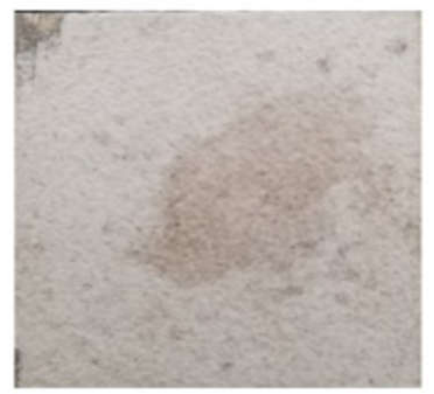

\section{Test sample before polarization test}

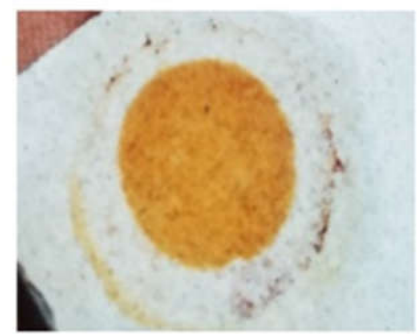

Test sample after polarization test

Figure 9: Test specimen before and after polarization test

It is apparent that corrosion rate is satisfactory and good enough for commercial applications. The result obtained is similar to that of stainless steel. But for advanced ceramics, a lower corrosion rate is desired. The reasons for a high corrosion rate generally are due to a high percentage of porosity, cracks, voids and oxidation networks. Porosity in HVOF sprayed coatings are generally of the order of 6 to 21 $\%$ by volume. Better process control and use of vacuum or use of inert shroud gas may be adopted to reduce the porosity levels. A denser coating can be achieved and enhanced corrosion rates can be ensured as denseness (impermeability) plays a major role in the corrosion resistance of coatings.

\section{Conclusions}

Ceramic Coating was carried out on Mild Steel using HVOF technique. Characterization studies like XRD, SEM, EDS, Coating thickness, Surface Roughness, coating adhesion and polarization test for corrosion were conducted. The XRD results showed the different phases present in the coating. The SEM and EDS techniques make it possible to identify and determine the microstructure and composition 
of the coated surface. The corrosion rate of $1.5562 \mathrm{~mm} / \mathrm{yr}$ was obtained in the Polarization test. The coated material is comparable to bulk SS and Nickel. This is an acceptable corrosion rate where we can use this for many marine applications. By taking the above shown results into consideration ceramic coatings can be done on mild-steel for extreme environmental applications. At the same time with better process control, and with the use of inert shroud gas or vacuum, the coating can be made denser resulting in an improved morphology devoid of defects like high porosity, voids and unmelted particles. This can enhance the life of the coating for many applications. Hence the future scope of the work will cover these aspects to make the coating denser and with fewer defects.

\section{Declaration of interest statement}

There is no conflict of interest in this work. This is the research work done by the author in his Institute.

\section{References}

1. Basu, S.N., Structure and properties of functionally graded environmental barrier coatings for ceramic components in gas turbines, International conference on advanced materials and composites (ICAMC-2007), Oct 24-26, organized by National Institute for interdisciplinary science and technology, CSIR, Trivandrum, 2007.

2. Juliana Anggono, Mullite Ceramics: Its Properties, Structure, and Synthesis, Jurnal Teknik Mesin, 2005, 7(2), 1-10.

3. B. Viswanath, S. Vijayarangan, Characterization studies of mullite coatings on cast aluminum, J. Therm. Spray Technol., 2011, 21 (2), 325-334.

4. M. BillahBhatty, F. Ahmad Khalid, and A. Nusair Khan, Behavior of Calcia-Stabilized Zirconia Coating at High Temperature, Deposited by Air Plasma Spraying System, J. Therm. Spray Technol., 2012, 21(1), 121-131.

5. D. J. Branagan, M. Breitsameter, B. E. Meacham, V.Belashchenko, High-Performance Nanoscale Composite Coatings for Boiler Applications, J. Therm. Spray Technol., 2005, 14 (2), 196-204.

6. G. I. Cubillos, J. J. Olaya, M. Bethencourt, G. Cifredo, and G. Blanco, Resistance to Corrosion of Zirconia Coatings Deposited by Spray Pyrolysis in Nitrided Steel, J. Therm. Spray Technol., 2013, 22(7), 1242-1252.

7. D. Fantozzi, V. Matikainen, M. Uusitalo, H. Koivuluoto, P. Vuoristo, Effect of Carbide Dissolution on Chlorine Induced High Temperature Corrosion of HVOF and HVAF Sprayed Cr3C2-NiCrMoNb Coatings, J. Therm. Spray Technol., 2018, 27, 220-231.

8. Hitesh Vasudev, Lalit Thakur, Amit Bansal, Harmeet Singh, Sunny Zafar, High temperature oxidation and erosion behaviour of HVOF sprayed bi-layer Alloy-718/NiCrAlY coating, Surf. Coat. Technol., 2019, 362, 366-380.

9. T. Hussain, D. G. McCartney, P. H. Shipway, T. Marrocco, Corrosion Behavior of Cold Sprayed Titanium Coatings and Free Standing Deposits, J. Therm. Spray Technol., 2011, 20(1-2), 260- 274.

10. Chen Jiang, Eric H. Jordan, Alan B. Harris, Maurice Gell, and Jeffrey Roth, Double-Layer Gadolinium Zirconate/YttriaStabilized Zirconia Thermal Barrier Coatings, Deposited by the Solution Precursor Plasma Spray Process, J. Therm. Spray Technol., 2015, 24(6), 895-906.

11. Anup Kumar Keshri and Arvind Agarwal, Wear Behavior of Plasma-Sprayed Carbon Nanotube-Reinforced Aluminum Oxide Coating in Marine and High-Temperature Environments, J. Therm. Spray Technol., 2011, 20(6), 12171230.

12. Heli Koivuluoto, JonneNa"kki, and Petri Vuoristo, Corrosion Properties of Cold-Sprayed Tantalum Coatings, J. Therm. Spray Technol., 2009, 18(1), 75 - 82.

13. S. Paul, B. Syrek-Gerstenkorn, Can Thermally Sprayed Aluminum (TSA) Mitigate Corrosion of Carbon Steel in
Carbon Capture and Storage (CCS) Environments, J. Therm. Spray Technol., 2017, 26, p 184-194.

14. J. H. Perepezko, T. A. Sossaman, M. Taylor, Environmentally Resistant Mo-Si-B-Based Coatings, J. Therm. Spray Technol., 2017, 26, 929-940.

15. SekarSaladi, Jyoti V Menghani, Satya Prakash, Characterization and Evaluation of Cyclic Hot Corrosion Resistance of Detonation-Gun Sprayed Ni-5Al Coatings on Inconel, J. Therm. Spray Technol., 2015, 24(5), 778-788.

16. T.S.Sidhu, A. Malik, S. Prakash, and R.D. Agrawal, Oxidation and Hot Corrosion Resistance of HVOF WC-NiCrFeSiB Coating on Ni- and Fe-based Super alloys at $800^{\circ} \mathrm{C}$, J. Therm. Spray Technol., 2007, 16(5-6), 844-849.

17. S Shrestha, A J Sturgeon, The use of advanced thermal spray processes for corrosion protection in marine environments, Surface Engineering, 2004, 20(4),237-243.

18. Y. Wang, Y.G. Zheng, W. Kea, W.H. Sun , W.L. Hou , X.C. Chang, J.Q. Wang, Slurry erosion-corrosion behaviour of highvelocity oxy-fuel (HVOF) sprayed Fe-based amorphous metallic coatings for marine pump in sand-containing $\mathrm{NaCl}$ solutions, Corrosion Science, 2001, 53, 3177-3185.

19. S. Vignesh, K. Shanmugam , V. Balasubramanian , K. Sridhar, Identifying the optimal HVOF spray parameters to attain minimum porosity and maximum hardness in iron based amorphous metallic coatings, Defence Technology, 2017, 13, 101-110.

20. Jin Kawakita, Seiji Kuroda, Takeshi Fukushima, Toshiaki Kodama, Development of dense corrosion resistant coatings by an improved HVOF spraying process, Science and Technology of Advanced Materials, 2003, 4, 281-289.

21. Richard Piolaa, Andrew S. M. Angb, Matthew Leighc, Scott A. Wadeb, A comparison of the antifouling performance of air plasma spray (APS) ceramic and high velocity oxygen fuel (HVOF) coatings for use in marine hydraulic applications, Biofouling, 2018, 34(5), 479-491.

22. https://www.mee-inc.com/hamm/electrochemicalcorrosion-testing/Electrochemical Corrosion Testing.

23. Roberta R. Moreira, Thiago F. Soares, Josimar Ribeiro, Electrochemical Investigation of Corrosion on AISI 316 Stainless Steel and AISI 1010 Carbon Steel: Study of the Behavior of Imidazole and Benzimidazole as Corrosion Inhibitors, Adv. Chem. Engineer. Sci., 2014, 4, 503-514.

24. O. I. Sekunowo, S. O. Adeosun, G. I. Lawal, Potentiostatic polarization responses of mild steel in seawater and acid environments, IJSTR, 2013, 2(10),139-145. 